\title{
New Dependency?: Economic Links between China and Latin America
}

\author{
Néstor Castañeda* \\ Forthcoming Issues 8 Studies
}

\begin{abstract}
This paper focuses on the most recent trends of Chinese finance (FDI and development loans) in Latin America and their impact on economic development. In particular, this paper explores the economic and institutional factors that attracts loans and FDI from China to Latin America. Based on data from the Chinese Ministry of Commerce and the United Nations on Chinese FDI and development loans to Latin America, this article argues that Chinese capital flows to the region, rather than politically motivated, are mainly motivated by trade interests, the evolution of the market of commodities, and natural resources-related policy goals. These capital flows are functional to the Chinese government's use of soft power in the region, but these goals are secondary to market-based interests.
\end{abstract}

Keywords: China, Latin America, Foreign Direct Investment, Trade, Economic Dependency

*Assistant Professor, University College London, E-mail: n.castaneda@ucl.ac.uk 


\section{Introduction}

Current trends in the economic relationship between China and Latin America attract considerable attention from scholars and policymakers. Total trade between China and Latin America has increased substantially in the past decade, and China is now one of the top trading partners for some of the major economies in the region (i.e. Argentina, Brazil, Chile, Colombia, Mexico, and Peru). FDI from China to Latin America has also expanded consistently since since 2000. The role of the Chinese government and its development agencies and banks is increasingly influential in the region, and more channels of cooperation seem to be available for China-Latin America economic relations.

There is empirical evidence that Latin American exports prices are increasingly driven by Chinese demand for natural resources and raw materials and there are symptoms of export dependency on China (Ortiz, 2012). These patterns of trade specialization (Latin America is a net exporter of primary products and a net importer of manufactures) pose serious threats on manufactures exporters and small agricultural firms (Lall \& Weiss, 2007; Gallagher \& Porzecanski, 2010; Gachúz, 2012; Gallagher, 2016), and jeopardize technological innovation in the region (Gallagher \& Porzecanski, 2010; Gallagher, 2016).

However, this booming relationship is not uniform across Latin America and only some few countries are truly engaged within the Chinese export-led development model. The role of Chinese trade and finance is not only heterogeneous but also relatively fragile across countries: while economic ties with commodity producers, natural-resources-oriented economies, and fiscal paradises are quite strong; the economic relationship between China and other economies is rather fragile. In fact, some scholars have presented evidence that refutes the notion that the long-term economic sustainability of Latin America is at risk because of the increasing trade dependency on China (Wise \& Quiliconi, 2007; Gallagher \& Irwin, 2015; Wise, 2016; Myers \& Wise, 2016). China's level of involvement in the region is still quite partial and sporadic. Trade with some countries has increased substantially, investments flows and stocks are larger and substantial, and some governments are quite active looking for 
stronger economic connection links. However, Latin American economies still have stronger links with the United States (e.g. Central America) and Western Europe (e.g. South America), and their trade links with China are not diversified enough to make them effectively dependent on the fluctuations of the Chinese economy.

This article argues that, despite the thriving trade between China and some Latin American economies, there is not a relationship of dependency, and both parts are rather enjoying or suffering the benefits and costs of global market cycles (Gallagher \& Porzecanski, 2010). The industrialization process in China is definitively shaping world commodity prices. Some Latin American economies have benefited from China's increasing demand for raw materials and they have also resented the implications of the slow economic growth in China and the subsequent fall of world commodity prices. However, most of the Latin American economies are not dependent on investment flows coming from China and the degree of participation of Chinese capitals in the region's industrial or agricultural sectors are still too weak ${ }^{1}$. Certainly, Chinese economic performance affects Latin American economic growth, but given the current patterns of regional integration to the global market, one cannot argue that Latin America is dependent on China or it will be in the near future.

The classic argument of the dependency theory is that global market conditions are structurally unfavorable for peripheral countries because they heavily rely on primary exports (i.e. heavily specialized production of commodities) and high-value manufactured imports from the industrialized center (Cardoso \& Faletto, 1979; Palma, 2016). But dependency theory also claims that these new forms of economic dependency go beyond unfavorable terms-oftrade for peripheral countries and are better expressed in the dynamics of foreign direct investment and the ownership patterns of the dependent economies' means of production (Cardoso, 1972). In this classical line of argumentation, the relation of dependency would be hardened by the increasing presence of foreign direct investment not only in primary and

\footnotetext{
${ }^{1}$ Some scholars show empirical evidence that recent changes in the political geography of global soy production have positioned China in a dominant position within the agribusiness sector in Latin America, especially in Argentina and Brazil (Oliveira \& Schneider, 2016)
} 
natural resources sectors, but also in strategic industrial and agricultural sectors.

Dependency theory also claims that these unequal relationships would lead to the stagnation of the industrialization process in the periphery (Cardoso \& Faletto, 1979; Palma, 2016). In particular, it argues that the interplay between internal and external structures in contemporary capitalism creates serious obstacles to economic growth and industrialization, and also has negative effects on income distribution and job creation (Furtado, 1976). In the economic relationship between China and Latin America, trade balance effectively favors the former. However, the economic relationship with China does not explain the structural problems and shortcomings of the Latin American industrialization process (Hausmann, 2011; Palma, 2011). The economic relationship between China and Latin America is disadvantageous for the latter, but it is not a relationship of economic dependency.

This article presents empirical evidence that, despite the fact that trade between China and Latin America is growing rapidly, the presence of Chinese (private and public) capitals and investments in Latin America is still limited and circumscribed to few economic sectors (i.e. natural resources extraction). Therefore, despite the risks associated to the increasing export dependency on China (especially for a handful of countries and economic sectors), Chinese inflows of private and public investments are still relatively small and have not dramatically distorted Latin American economies or destroyed their industrial sectors (except in some few cases). Latin American economies do not substantially rely on foreign capital from Chinese multinational corporations and only few governments in the region heavily depend on Chinese development or private loans. The end of the commodity super-cycle has effectively had a significant impact on a number of Latin American economies, however, these negative outcomes are not only explained by the dynamics of their relationship with China and their effect on unemployment are still minimal. Finally, unequal trade exchange could actually suffocate technological innovation in Latin America, but this is neither a new problem for the region nor a peculiar characteristic of its relationship with China.

Finally, this article also shows that, contrary to classic theories of economic dependency, 
the economic relationship between China and Latin America has no significant political implications in the region. In fact, trade and investment flows between China and Latin America seem to be mainly market-driven and socio-political factors are indeed secondary. Not only Chinese foreign policy is well-known for its soft-power approach, but also domestic politics in Latin America is becoming increasingly independent from the influence of foreign global powers.

This article is organized as follows. First, we describe the most recent trends of trade exchange between China and Latin America. Second, we focus on the dynamics of foreign direct investments inflow from China to Latin America. Third, we briefly present some stylized data on the distribution of Chinese development loans in the region. Finally, we discuss the main findings and their implication for the analysis of the future of the economic relationships between China and Latin America.

\section{Trade between China and Latin America}

Trade between China and Latin America has expanded in an unprecedented way in the past fifteen years. China's impressive economic growth has fueled an unprecedented demand for raw materials and services and this demand has been mainly captured by East Asian, and Latin American countries. In fact, trade between China and Latin America increased 22-fold since 2000 (OECD/ECLAC/CAF, 2015). Figure 1 shows some details of the China-Latin America trade in the past twenty years. Panels (a) to (f) show the magnitude of trade flows between China and the main six economies of the region (Argentina, Brazil, Chile, Colombia, Mexico, and Peru). In all cases, there is a substantial increase of trade with China in the 2000s. For example, exports from China to Argentina, Colombia, or Peru increased from less than US $\$ 1$ billion in 2000 to about US $\$ 10$ billions in 2014 . Meanwhile, these countries increased their exports to China from less than US $\$ 1$ billion in 2000 to around US $\$ 5$ or US $\$ 6$ billions in 2014. Exports from China to Brazil surpassed US $\$ 40$ billions in 2014. In the same 
year, Brazil exported more than US\$35 billions in good and service to China.

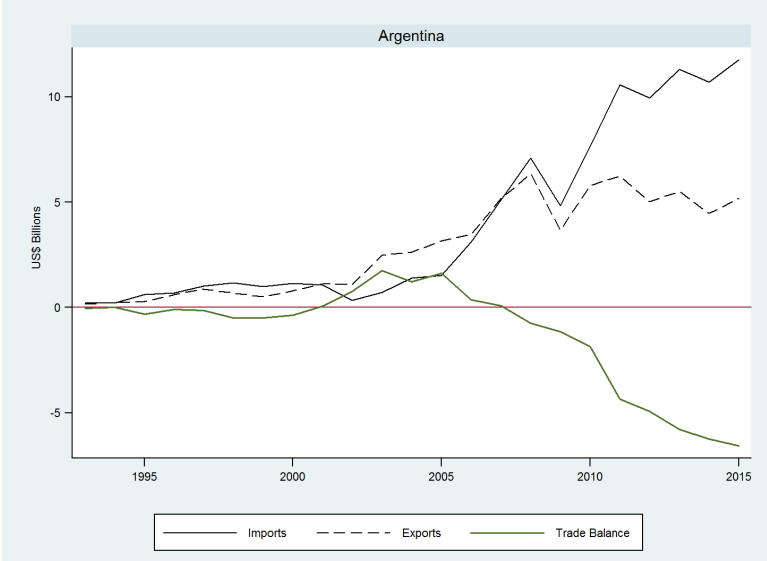

(a)

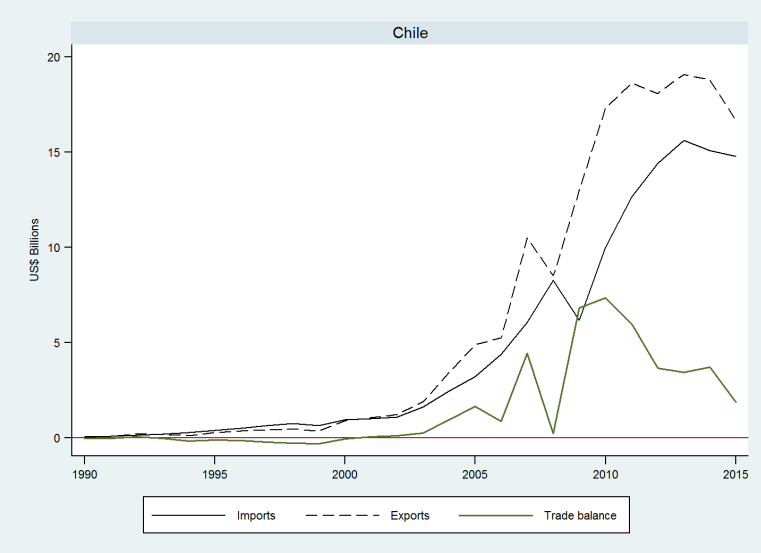

(c)

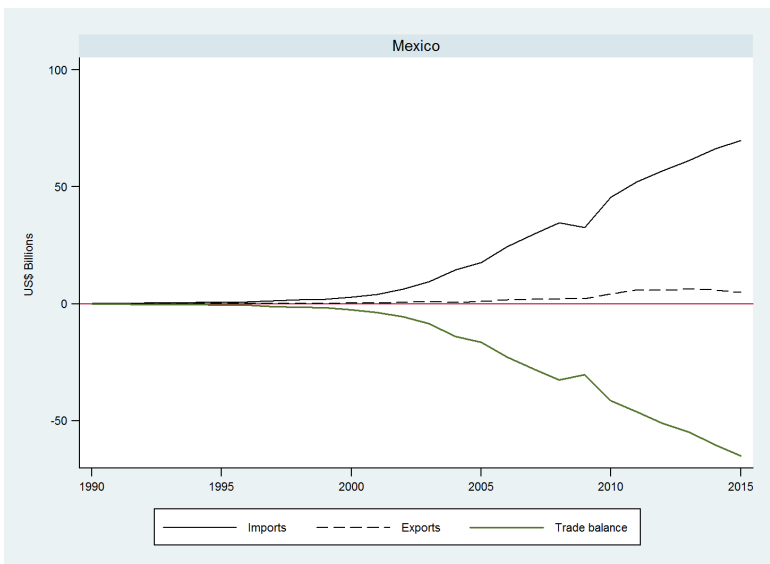

(e)

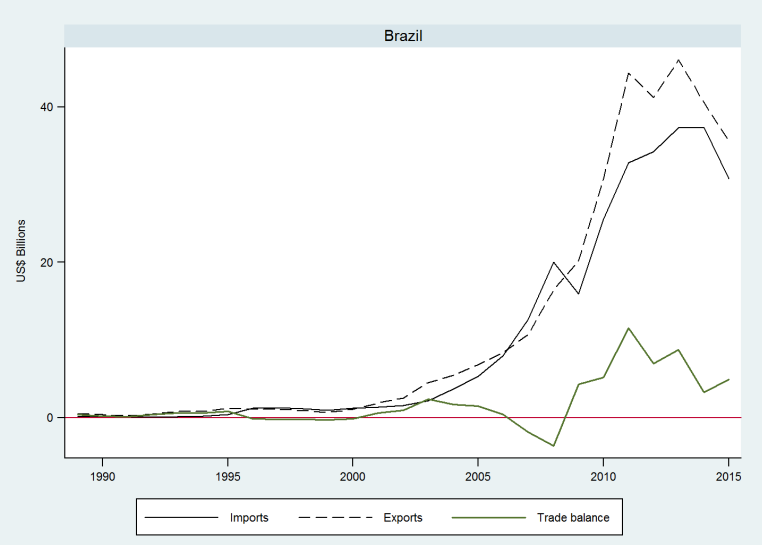

(b)

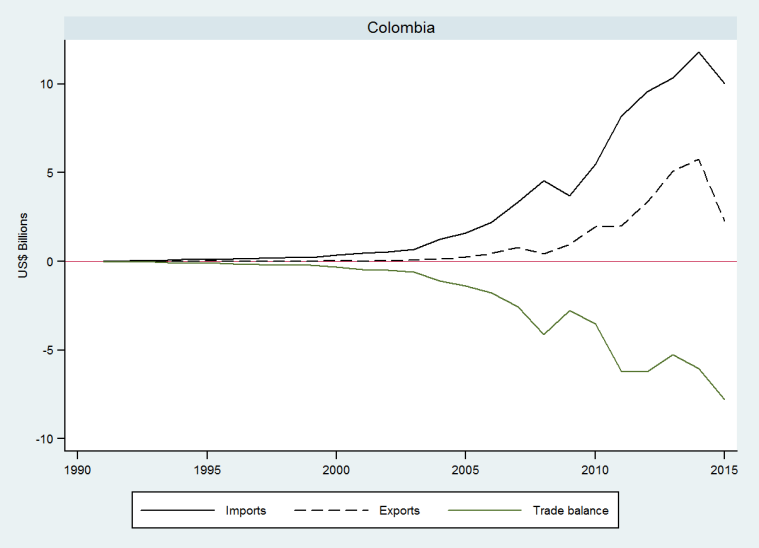

(d)

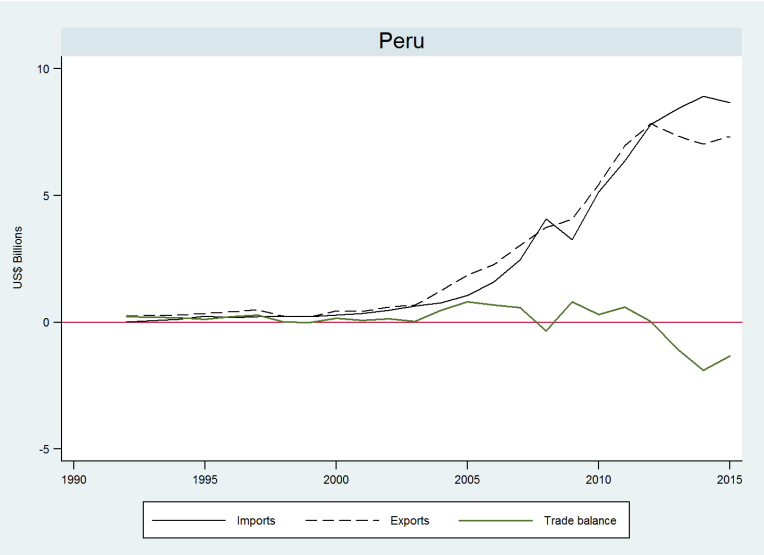

(f)

Figure 1: Trade volumes and balance between China and Latin American Countries. Source: UN COMTRADE Database 
The spectacular dimensions of these trade flows have obviously impacted the performance and structure of the Latin American economies (Ellis, 2009; Jenkins \& Peters, 2009; Gallagher \& Porzecanski, 2010; Wise, 2016). It is indisputable that the impressive performance of many Latin American economies was propelled by Chinese demand for commodities. In fact, some scholars have calculated that, conditional to the value of Chinese GDP growth, the value of Latin American exports to China would increase between $4.5 \%$ and $10 \%$ a year in the period 2014-2019 (Perrotti, 2015). Despite this astronomical growth and its potential impact on the region's long term economic growth, China-Latin America trade is still very limited (at least in comparison with Chinese trade with other regions ), not very diversified (trade is quite concentrated in a small number of commodities), and only some few countries really benefited from the commodities boom (OECD/ECLAC/CAF, 2015).

The benefits of trading with China are highly concentrated in a few countries. Figure 1 shows that although trade volumes increased for all the countries in the region, only few of them were capable of increasing their exports to China. In fact, China has become the largest trading partner for Brazil, Chile, and Peru, and the dynamism of such relationship is well described by positive or almost positive trade balance between those countries and China (panels b, c, and $\mathrm{f}$ in Figure 1). This is particularly remarkable in the cases of Brazil and Chile that have multiplied their exports to China almost twenty and forty times (correspondingly) since 2000 and have reported systematic trade balances with China over the past fifteen years.

In contrast, the export boom was not enough to counterbalance the massive amount of imports from China to countries like Argentina, Colombia, or Mexico. For example, Figure 1 shows that the expansion of trade between China and Argentina, and between China and Colombia, has lead to systematic and negative trade balance in both countries (despite the spectacular increase of exports to China since early 2000s). Mexico seems to have the most unbalanced trade relationship with China. While imports from China increased almost 70fold since the late 1990s, Mexican exports to China did not increase significantly over the 
same period. Panel (e) in Figure 1 shows the significant and negative dimension of the trade balance between Mexico and China. In the case of Central American countries, little complementaries with Chinese demand for primary products and high levels of dependence on the US market have kept them away from the benefits of the export boom (Avendano \& Dayton-Johnson, 2015). Avendano \& Dayton-Johnson (2015) also note that diplomatic factors could be also relevant to explain the weakness of the economic link between China and Central America: most of Central American countries have diplomatic relationship with Taiwan but not with China.

The cross-country variation in the effect of trade between China and Latin America could be also identified in the analysis of global value-added chains. Latin American countries insert themselves through different goods within such value-added chains and that makes them more or less susceptible to changes in Chinese demand for commodities and raw materials. For example, Brazil and Argentina are highly integrated to China's agricultural value-added chain (their exports contribute substantially to this chain), while Chile and Costa Rica are marginally integrated because their main exports to China are low technology manufactures (OECD/ECLAC/CAF, 2015, 106-107). Therefore, Brazil and Argentina are more sensitive to changes in the Chinese final demand for agricultural goods.

Latin American exports to China are still a very low proportion of the total regional exports - around 10\% of the total in 2014 - (also see Gallagher \& Porzecanski (2010); OECD/ECLAC/CAF (2015)) and China's imports from Latin America do not reach 5\% of its total imports. Over the past two decades the presence of Chinese imports in the region has substantially increased but it is not the region's main source of imports (especially in South America, where trade with the US and the European Union is quite intense). Table 1 shows that exports to China have increased substantially in Brazil (from 3\% to 18\% of total exports between 2001 and 2014), Chile (from 6\% to $25 \%$ of total exports between 2001 and 2014), and Peru (from 6\% to 18\% of total exports between 2001 and 2014). In contrast, exports from Argentina only increased from $4 \%$ to $7 \%$ (of the total exports) and exports 
from Colombia only increased from $1 \%$ to $11 \%$ (of the total exports) in the same period of time. As noted above, trade between Mexico and China is completely unbalanced. Mexican exports to China (as \% of the total exports) are modest and have not increased at all in the past 15 years. In the meantime, imports from China to the main Latin American economies (as \% of total imports) increased from single digits to almost $20 \%$ in the same period of time.

Table 1: Trade indicators China-Latin America as \% of total exports

\begin{tabular}{|c|c|c|c|c|c|c|}
\hline & & & & & & \\
\hline \multicolumn{7}{|l|}{ ARGENTINA } \\
\hline Exports to China & 4 & 8 & 9 & 6 & 7 & 7 \\
\hline Imports from China & 5 & 5 & 11 & 15 & 15 & 16 \\
\hline \multicolumn{7}{|l|}{ BRAZIL } \\
\hline Exports to China & 3 & 6 & 7 & 17 & 19 & 18 \\
\hline Imports from China & 2 & 7 & 10 & 15 & 16 & 16 \\
\hline \multicolumn{7}{|l|}{ CHILE } \\
\hline Exports to China & 6 & 12 & 15 & 23 & 25 & 25 \\
\hline Imports from China & 6 & 10 & 13 & 18 & 20 & 21 \\
\hline \multicolumn{7}{|l|}{ COLOMBIA } \\
\hline Exports to China & 0 & 1 & 3 & 6 & 9 & 11 \\
\hline Imports from China & 4 & 8 & 10 & 17 & 18 & 19 \\
\hline \multicolumn{7}{|l|}{ MEXICO } \\
\hline Exports to China & 0 & 1 & 1 & 2 & 2 & 2 \\
\hline Imports from China & 2 & 8 & 11 & 15 & 16 & 17 \\
\hline \multicolumn{7}{|l|}{ PERU } \\
\hline Exports to China & 6 & 11 & 11 & 18 & 17 & 18 \\
\hline Imports from China & 5 & 8 & 12 & 18 & 19 & 21 \\
\hline
\end{tabular}

The empirical evidence presented in Figure 1 and Table 1 also suggests that there are at least two patterns to describe China-Latin America trade relations. On the one hand, South American countries have developed a more balanced trade exchange with China and some countries (Brazil, Chile and Peru) have had trade surpluses in the past few years. On the other hand, Mexico and Central American countries have had a systematic trade deficit since 2000. In fact, the whole region's trade deficit is explained by Mexico and Central 
America's growing negative trade balance with China (ECLAC, 2015, 38). In the case of the Caribbean, most countries also have trade deficits with China, but this is reasonable given the size and complexity of their economies and the fact that they are then main recipients of Chinese FDI in the region (Garcia-Herrero et al. , 2015).

Exports from Latin America to China are primarily commodities. In fact, commodities account for almost $80 \%$ of Latin American exports to China. This is the main attribute of China-Latin America trade: Latin American exports to China are less sophisticated than exports to other regions. With only some few exceptions, Latin American countries barely exported low, medium, or high technology manufactures to China (ECLAC, 2015). Table 2 shows that, for example in 2011, commodities accounted for about $63 \%$ of exports from Argentina to China, $58 \%$ of exports from Brazil, $57 \%$ of exports from Colombia, and $100 \%$ of the exports from Peru (OECD/ECLAC/CAF, 2015). In the meantime, medium and high technology exports to China only accounted for 3\% from Argentina, 5\% from Brazil, and $1 \%$ from Chile or Colombia. The only exception to this trade specialization pattern is Chile that has been able to build links with China beyond commodities trade. For example, 60\% of Chilean exports to China in 2011 were low-technology manufactures.

Table 2 also shows that imports from China are mostly low, medium, and high technology manufactures. Manufactured goods account from almost $80 \%$ of the exports from China to Argentina, $77 \%$ of the exports from China to Brazil, $82 \%$ of the exports to Colombia, and $86 \%$ of the exports from China to Mexico. Commodities trade from China to Latin America is practically inexistent. Therefore, there is a clear inter-industry trade of commodities in exchange for manufactures (ECLAC, 2015, 43) between China and Latin America. ${ }^{2}$ This pattern will not change because Chinese demand for food and energy is expected to increase in the next few decades, and Latin American countries have large and growing surpluses with China in agricultural trade (almost US\$40 billions in 2015). Like in the case of general trade, there is a high concentration of agricultural trade in terms of origin and products, and

\footnotetext{
${ }^{2}$ Here it is very important to observe that these trade patterns also depend on the attributes of Chinese industrialization and China's role in the global market, please see Nolan (2005)
} 
only some few countries are enjoying or will enjoy the benefits of this buoyancy given their competitive advantages in the agricultural sector (e.g. Argentina, Brazil, and Uruguay) or simply because they have recently signed free trade agreements with China (Chile, Costa Rica and Peru).

Table 2: Trade China-Latin America decomposed by sector, 2011

\begin{tabular}{|c|c|c|c|c|c|}
\hline & Agriculture & Mining & $\begin{array}{l}\text { Low and } \\
\text { medium- } \\
\text { low tech }\end{array}$ & $\begin{array}{l}\text { Medium- } \\
\text { high and } \\
\text { high tech }\end{array}$ & Services \\
\hline \multicolumn{6}{|l|}{ ARGENTINA } \\
\hline Exports to China & 57 & 6 & 17 & 3 & 17 \\
\hline Imports from China & 0 & 0 & 19 & 58 & 23 \\
\hline \multicolumn{6}{|l|}{ BRAZIL } \\
\hline Exports to China & 14 & 44 & 15 & 5 & 21 \\
\hline Imports from China & 0 & 0 & 22 & 55 & 22 \\
\hline \multicolumn{6}{|l|}{ CHILE } \\
\hline Exports to China & 2 & 19 & 60 & 1 & 18 \\
\hline Imports from China & 0 & 8 & 14 & 31 & 47 \\
\hline \multicolumn{6}{|l|}{ COLOMBIA } \\
\hline Exports to China & 0 & 57 & 26 & 1 & 17 \\
\hline Imports from China & 0 & 0 & 30 & 52 & 18 \\
\hline \multicolumn{6}{|l|}{ MEXICO } \\
\hline Exports to China & 1 & 30 & 12 & 40 & 17 \\
\hline Imports from China & 0 & 0 & 19 & 67 & 14 \\
\hline \multicolumn{6}{|l|}{ PERU } \\
\hline Exports to China & 30 & 70 & 0 & 0 & 0 \\
\hline Imports from China & 1 & 7 & 31 & 31 & 30 \\
\hline
\end{tabular}

The empirical evidence in this section has demonstrated that there are clear patterns of trade integration between China and Latin America and one could argue that they resemble a relation of economic dependence. However, this empirical evidence also shows that the characteristics and dimensions of this trade relationship are not homogeneous across the region or across economic sectors. Consequently, the benefits and costs of the spectacular growing of trade exchange with China are, in most of the cases, rather limited. Trade links with China are effectively stronger and highly beneficial for China (in some cases they are 
actually quite beneficial for Latin American economies too), but they are not shaping a relation of dependency like predicted by many scholars and pundits.

China's economic influence over Latin America is conducted mostly through trade and not through capital investment. However, its role in trade exchange is still limited and quite heterogeneous across the region. The volumes of China-Latin American trade are still smaller than the volumes of trade between Latin America and the US or the European Union.

\section{Capital transfers}

\section{Foreign Direct Investment}

Chinese outward FDI has grown substantially since the financial crisis in 2008. According to official data provided by Chinese authorities (Ministry of Commerce, 2015), in the past few years most of the Chinese FDI has flowed to Asia (about 70\% of total Chinese outward FDI) and Latin America (about 13\% of total Chinese outward FDI). The main targets of Chinese capital investments are leasing and business services (investments in holding companies in tax havens that are use for cross-border mergers and acquisitions), financial intermediation, and mining (Ministry of Commerce, 2015). The presence of Chinese FDI in Latin America has increased in a meaningful way since 2010 and several Chinese companies are among the biggest investors in oil, mining and gas industries in countries like Argentina, Brazil, Chile, Colombia, Ecuador and Peru. Meanwhile, other major economies (e.g Mexico and Chile) and economic sectors (e.g. financial services) have not yet attracted Chinese capitals.

Despite the increasing amount of Chinese FDI in the region, "investment relations between China and Latin America are not on a par with their trade relations" (Chen \& Perez, 2014, 14). First of all, official statistics overestimate Chinese FDI flowing into the region by including round-tripping destinations (or tax havens) as part of Latin American and the Caribbean. Most of the Chinese FDI flows are channeled through stopover locations or tax havens in order to pay lower taxes or return capital investments to China as they were FDI 
(Garcia-Herrero et al. , 2015). Tax havens in the Caribbean are one of the preferred destinations for off-shoring and round-tripping Chinese investors, and they are generally included in the official statistics as part of Latin America.

For example, recent estimations show that Chinese FDI flows in 2013 were much lower than those reported by the Chinese Ministry of Commerce (US\$108 billion) and were actually closer to US\$82 billion (Garcia-Herrero et al. , 2015, 7). Garcia-Herrero et al. (2015) also show that the actual geographical distribution of Chinese FDI is also quite different. Asia is by far the main destination for Chinese FDI flows and stocks. However, Latin America is definitively not the second largest recipient of FDI from China. Controlling for off-shoring and round-tripping, Europe emerges as the second largest destination (17\% of total FDI flows) and North America emerges as the third largest destination (14\%). According to Garcia-Herrero et al. (2015), Latin America only attracted 5\% (not 13\%) of the Chinese FDI flows in 2013. If we adjust data on FDI flows for off-shoring and round-tripping (investments that are channeled through the Caribbean and Panama but never stay in Latin American and the Caribbean), Chinese FDI flows to the region are actually very limited (even if we use official data from Chinese authorities).

Figure 2 shows FDI (flows) from China to Latin America between 2003 and 2014. The solid black line represents FDI from China in US\$ million and bars represent FDI from China as percentage of the total inflow of FDI to Latin America in the same period of time. We may note that Chinese FDI to Latin America has grown spectacularly since 2010. FDI from China increased from almost zero in the early 2000s to about US\$150-200 million in Colombia, Mexico or Peru; US\$1 billion in Argentina and Brazil, and more than US\$1 billion in Venezuela in the 2010s.

Contrary to trade exchange, FDI from China has been quite irregular in the past few years. The new outburst of Chinese FDI is a direct consequence of recent acquisitions in the oil, gas, and mining industry. For example, Chinese companies acquired major oil companies in Argentina and Brazil, bought mining companies in Peru, and invested large amounts of 
capital in oil joint ventures in Venezuela. This sudden increase in the number of capital ventures explains the irregular patterns of FDI (solid black lines) in Figure 2 and show evidence that Latin America is still an unsteady recipient of Chinese capital investments (at least, in comparison with Asia and Western Europe). Capital penetration in the region is not consistent over time, does not have an impact in most of the major regional economies (e.g. Chile, Colombia, or Mexico have barely attracted FDI from China), and depends on sporadic capital ventures targeting oil, gas, and mining industries.

Figure 2 shows that Argentina, Brazil, and Venezuela have been the main recipients of Chinese FDI since 2010. This is not surprising because, as noted above, FDI from China is not only unsteady, but mainly concentrated in raw material industries: oil and gas extraction, mining, and power generation. Chinese capital ventures in other economic sectors are scarce. ${ }^{3}$ Also, Chinese FDI has rarely been more than US\$300 million a year in the Andean countries (Colombia, Ecuador, or Peru) and has been quite modest in Chile and Mexico.

Contrary to common wisdom, the penetration of Chinese capitals in the region is still vacillating. In fact, Figure 2 shows that FDI from China do not account for more than $5 \%$ of the total FDI inflows in most Latin American countries (please see the bars). The acquisitions of oil companies in Argentina between 2011 and 2014 only account for $4 \%$ of $5 \%$ of the total FDI inflows. Chinese investments and joint ventures in the Brazilian oil industry hardly accounts for $2 \%$ of the FDI inflows attracted to Brazil between 2010 and 2014. Chinese FDI in Chile, Colombia, Mexico, and Peru has been also limited (never more than US $\$ 200$ million in the period under analysis) and does not account for more than $2 \%$ of the FDI inflows to these countries.

Bolivia, Ecuador, and Venezuela are the exception to the pattern described above. Chinese FDI accounted for half of total FDI inflows to Ecuador in 2012, and more than $60 \%$ of total FDI inflows in 2013. Similarly, FDI from China accounts for about $40 \%$ of total FDI

\footnotetext{
${ }^{3}$ According to Chen \& Perez (2014), we can expect more FDI from China to the agricultural sector, because demand for food is increasing and the Chinese is implementing large-scale plans to cope with future food security issues
} 


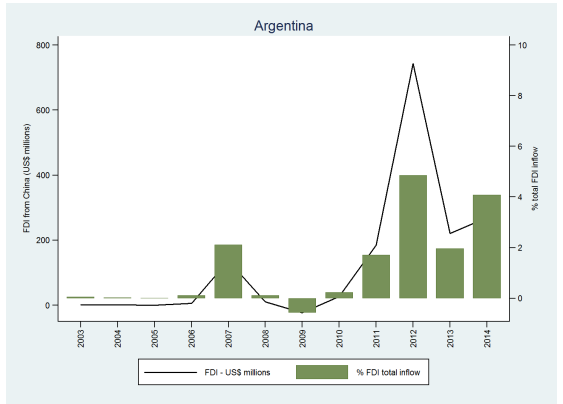

(a)

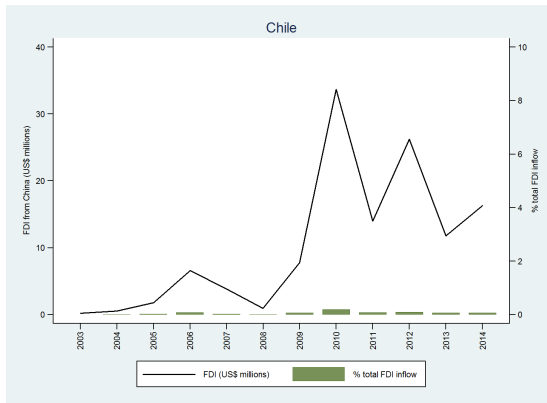

(c)

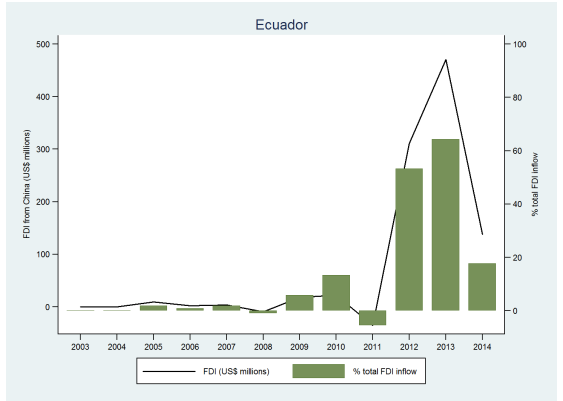

(e)

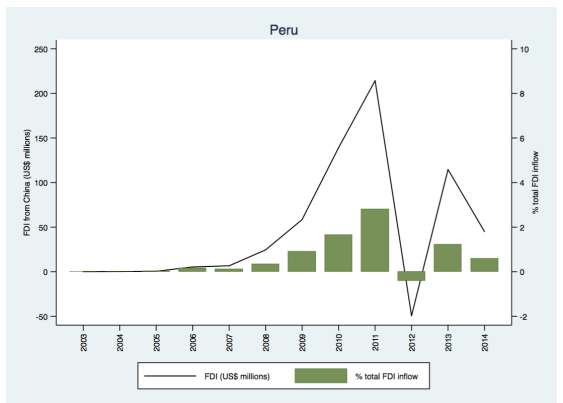

(g)

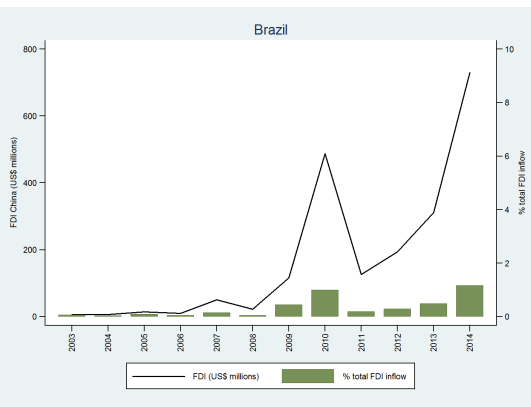

(b)

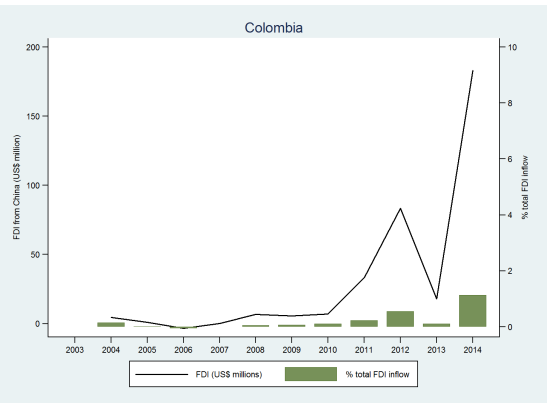

(d)

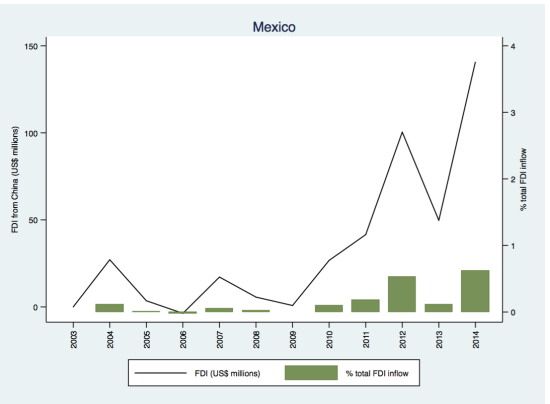

(f)

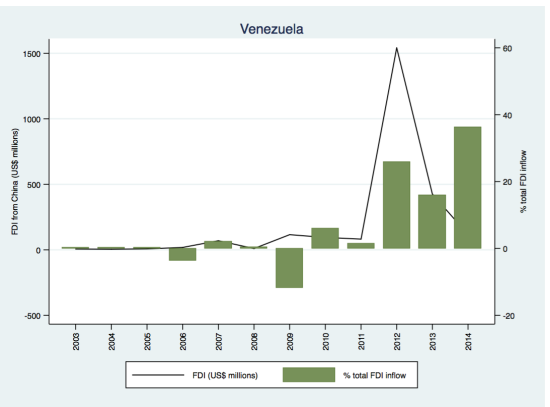

(h)

Figure 2: FDI flows from China to Latin America (US\$ millions and \% total FDI inflows). Source: Chinese government, MOFCOM 
inflows to Venezuela in 2014. However, these capital investments are still quite unsteady and mostly the consequence of the on-going political unrest, the sharp fall of the international oil prices in 2014-15, and the lack of access to traditional sources of capital investment.

In contrast with the modest contribution of Chinese FDI to the total FDI flowing to Latin America, Figure A2 (in the Appendix) shows that FDI from the United States accounts for a substantial portion of the capital investments coming to the region. For example, contrary to politician's rhetoric and pundits' opinion, FDI from US to Argentina (in average) accounts for more than 25\% of total inward FDI in 2010 and for more than half of the FDI inflows in 2014. Not surprisingly, FDI from the US to Mexico is quite substantial and consistent. American FDI accounts for almots half of the FDI inflows to Mexico over the past 15 years. FDI from the US is less important for other major economies in the region (e.g. Brazil, Chile or Colombia), but it still accounts for about $20 \%$ of the FDI they receive annually.

The relative limited penetration of Chinese FDI in Latin America might be also fully apprehended from the perspective of the country of origin. Figure A1 (in the Appendix) show FDI from China to Latin America as percentage of total outward Chinese FDI. FDI to major Latin American economies does not account for more than $2 \%$ of total outward Chinese FDI. The main recipients of Chinese FDI in the region (Argentina, Brazil, and Venezuela) do not receive more than $3 \%$ of total outward Chinese investments. Chinese FDI in other major economies like Chile, Colombia or Brazil does not account for more than 0.5\% of the total Chinese FDI in the past few years.

The evidence presented above shows that Chinese capital investments have a growing but still quite limited role in Latin America. Chinese FDI seems to be focused on extraction industries, natural resources, and infrastructure. Only in some few and isolated instances (e.g. Brazil), Chinese FDI has been directly targeted to the manufacturing sector (Chen \& Perez, 2014; ECLAC, 2015). But, what are the determinants of FDI from China in Latin America? What is driving the investors' interest in the region? From a traditional point of view, one could argue that they are only interested in countries with substantial oil, gas, and 
mining sectors. However, FDI from China is also going to countries with not very impressive natural resources endowments. Does trade drive FDI from China?

Table 3 presents a preliminary statistical analysis of the determinants of Chinese FDI flowing to Latin America. Using a fixed-effects cross-sectional regression model, I estimate the effects of economic and institutional factors on the FDI from China. In particular, I test the hypothesis that trade-related factors are more important in explaining FDI from China than institutional or political factors (Wei, 2000; Carr et al. , 2001; Di Giovanni, 2005; Büthe \& Milner, 2008; Blonigen \& Piger, 2014; Julio \& Yook, 2016). If this hypothesis is correct, it contradicts theories arguing that FDI is mainly driven by the size of the markets and political/geostrategic reasons (Tuman \& Emmert, 1999; Bengoa \& Sanchez-Robles, 2003; Biglaiser \& DeRouen, 2006; Montero, 2008; Amal et al. , 2010; Corrales \& Penfold-Becerra, 2011; Staats \& Biglaiser, 2012).

The outcome variable is the volume of FDI flows from China in US\$ billion and is measured using official data provided by the Chinese Ministry of Commerce (2015). For the main explanatory factor -"trade intensity" -, I use the volume of imports from China to Latin America in US\$ billion (data extracted from UN-ECLAC), the country-level index of trade openness (data from UNCTAD), and the official domestic exchange rate in US\$ constant terms (data from UNCTAD). In order to measure the impact of institutional and political factors, I use an index of investment country risk (data from ICRG), an index of government stability (data from ICRG), and a metric of government ideology (data from the World Bank). The investment risk country profile, constructed by the International Country Risk Guide Dataset, evaluates investment risk factors associated with contract viability/expropriation, profits repatriation and payments delays, and it ranges from low to high risk (PRS, 2015). The index of government stability (also provided by the International Country Risk Guide Dataset) measures the level of government unity, legislative strength, and popular support (PRS, 2015).

I collected data for all these variables for the ten major economies of the region (Ar- 
gentina, Bolivia, Brazil, Chile, Colombia, Ecuador, Mexico, Panama, Peru, and Venezuela) between 2003 and 2014. Given the structure of the dataset (i.e. panel data), I use fixed effects cross-sectional linear models to estimate the effects of covariates on the outcome variable. Results are presented in Table 3.

Model (1) in Table 3 evaluates the effect of trade-related factors vs. the effect of institutional risks on Chinese FDI flows to Latin America. Model (2) examines the effect of trade-related factors vs. government stability. And finally model (3) evaluates the effect of trade-related factors vs. government ideology. The results presented in Table 3 are consistent and quite meaningful. The intensity of trade relationships between China and Latin American countries (measured as the volume of imports from China) consistently explain the dynamics of Chinese FDI in the region. These results suggest that FDI comes with trade penetration. Chinese FDI not only goes to countries where trade links with China are dynamic, but also to countries where exchange rates make investment returns more competitive in the global market. That explains why currency depreciation attracts export-oriented Chinese FDI to Latin America. Results presented in Table 3 also suggest that the degree of trade openness has no significant effect on FDI from China. Thus, FDI is not attracted by potential trade opportunities; it is attracted by on-going trade links.

Models (1) to (3) in Table 3 also show that the effect of political institutions on Chinese FDI flowing to Latin America is rather limited. Institutional risks for investment are definitively a relevant factor: Chinese FDI flows significantly increase as investment risks like contract viability/expropriation, profits repatriation and payments delays are lower. However, the degree of government stability or the government ideology seem to be non-significant predictors of Chinese FDI flows to Latin America. In contrast with American investors, Chinese companies seem to be less concerned about institutional or political stability.

In fact, the results presented in Table 3 not only provide evidence that Chinese presence in Latin America is mainly economically driven (or even trade driven), but also show that 
Table 3: Determinants FDI from China to Latin America, Fixed-effects (within) regression

\begin{tabular}{lccc}
\hline \hline & $\begin{array}{c}(1) \\
\mathrm{b} /(\mathrm{se})\end{array}$ & $\begin{array}{c}(2) \\
\mathrm{b} /(\mathrm{se})\end{array}$ & $\begin{array}{c}(3) \\
\mathrm{b} /(\mathrm{se})\end{array}$ \\
\hline Imports from China (US\$ billions) & $4.202^{* *}$ & $3.525^{* *}$ & $3.505^{* *}$ \\
& $(1.65)$ & $(1.65)$ & $(1.63)$ \\
Trade Openness & -1.137 & -1.817 & -2.740 \\
& $(1.95)$ & $(2.01)$ & $(2.07)$ \\
Exchange rate (domestic to US\$) & $0.573^{* *}$ & $0.5699^{* *}$ & $0.554^{* *}$ \\
& $(0.25)$ & $(0.25)$ & $(0.25)$ \\
Investment risk country profile (from high to low) & $38.055^{* *}$ & & \\
& $(18.15)$ & & \\
Government stability risk (from high to low) & & -0.592 & \\
& & $(0.97)$ & \\
Government ideology (from right to left) & & & 39.53 \\
& & & $(31.06)$ \\
\hline$N$ & 99 & 99 & 99 \\
$R^{2}$ & 0.213 & 0.172 & 0.187 \\
Rho (fraction of variance due to unit effects) & 0.62 & 0.58 & 0.64 \\
\hline \hline
\end{tabular}

Chinese capital penetration has little to do with political or ideological reasons. Although substantial amounts of FDI outward flows are channeled through state-owned companies (e.g. state-owned-oil companies), they do not seem to be allocated according to an ideological or "soft-power" logic. Chinese FDI flows towards Latin American seem to be driven by the existence of trade links and the availability of natural resources. This analysis confirms the export-oriented nature of Chinese FDI in Latin America.

\section{Chinese lending}

Recent scholarship on Sino-Latin American relations claims that China has emerged as the new biggest Latin American creditor and is providing alternative funding for governments in the region to increase their budgetary spending in times when access to global capital markets is limited for emerging and developing countries (Kaplan, 2013, 2015). From this perspective, the commodities boom and the increasing Chinese state-led lending have endowed Latin American governments with greater fiscal space and made them able to keep significant fiscal deficits. Kaplan (2015) actually argues that the availability of state-to-state financing with no market conditionalities increased Latin American governments' (especially left governments) 
policy freedom to use fiscal deficits and stimulate domestic economies.

However, the effects of Chinese finance on fiscal policymaking in the region are rather limited. On the one hand, the fiscal effects of Chinese lending are conditional to the investment channels, and there is evidence that they would only work if received through development funding - not through private banks (Kaplan, 2015). This is the case of Venezuela where Chinese lending increased substantially after 2008, and according to (Kaplan, 2015, 14), it fuelled government's sizeable budget deficits since then. Brazil also received a substantial amount of loans from Chinese development banks, but most of them were channelized through the private sector and were not use to fund budget deficits. Additionally, Chinese development loans actually carry more stringent terms than Western banks loans (Gallagher et al. , 2012), which makes them less functional as fiscal policy tools.

On the other hand, Chinese lending to Latin American governments is relatively small and too focused on countries that are not able to borrow as easily in global capital markets (Gallagher \& Myers, 2015). Chinese lending going to Latin America between 2005 and 2015 has been mainly channeled through the China Development Bank (about 80\% of the total) and the China Export-Import Bank (about 20\% of the total), and increased from about US $\$ 30$ million to US $\$ 35$ billion in 2010, and US $\$ 29$ billion in 2015 (Gallagher \& Myers, 2015). The significant expansion of commercial and policy lending is a result of recent policy reforms in China that are aimed to increased the country's global presence and open up investment opportunities in emerging countries. However, in the case of Latin America, this lending policy does not have any consistent patterns, it is concentrated among some few borrowers (according to recent calculations, "the governments of Venezuela, Brazil, Argentina, and Ecuador received 91 percent of the total" (Gallagher et al. , 2012, 5)), and most of the loans are loans-for-oil (Gallagher \& Myers, 2015).

Based on data provided by Gallagher \& Myers (2015), Figure A3 shows the value of Chinese development loans to the main recipients since 2005. Argentina and Brazil received substantial loans mainly aimed to improve their transportation and infrastructure (e.g. high- 
speed trains, cargo train lines and hydroelectric dams in Argentina; and gas pipelines in Brazil). In the case of Brazil, Chinese lending is framed within a long-term bilateral cooperation agreement to fund energy production projects in exchange of oil. Ecuador received about US $\$ 15$ billion from Chinese development banks between 2005 and 2015 to fund energy generation projects (e.g. Minas-San Francisco hydroelectric dam), infrastructure (e.g. a new road to Quito airport), and the government's budget deficit (December 2012). In Bolivia, Chinese lending has focused on funding infrastructure (e.g. Rurrenabaque-Riberalta highway) and transportation projects projects (e.g. purchase of Chinese buses).

The government of Venezuela is the main recipient of Chinese lending in the region. Between 2005 and 2015, Venezuela received near US\$65 billion from different Chinese development banks. Most of the projects funded by Chinese banks are focused on energy generation and improving oil production. For example, the Chinese government is funding refineries (e.g. Abreu e Lima refinery) and state-owned oil fields (e.g. Sinovensa project in Orinoco). Like in Brazil, the Chinese government has implemented bilateral cooperation agreements with Venezuela that are mainly focused on improving and making oil production more efficient.

As noted above, Chinese lending in the past decade has mainly targeted oil and gas producers in Latin America. Minor oil producers (e.g. Colombia) or countries closely connected to the U.S. economy (e.g. Mexico) has received close to none lending from China. In other words, development loans are strategically allocated to facilitate China's energy policy. In fact, most of these loans can be correctly classified as loans-for-oil bilateral agreements (Gallagher et al. , 2012, 2013).

The dimension of the Chinese lending to oil and gas producers in the region could erroneously make us conclude that China is the most important source of finance for the region. As noted above, Chinese lending has a spectacular, but quite limited role in terms of providing alternative sources of funding for most of the governments in the region. Despite the fact that Chinese lending coming to the region between 2005 and 2011 is higher than the 
amount of resources coming from the World Bank or the Inter-American Development Bank (Gallagher et al. , 2012), most of the governments in the region have closer and more institutionalized relationships with Western lenders. For example, most of social, education, and environmental policies in the region are funded with Western loans. Chinese development banks have basically no role in the implementation of more sustainable development policies in Latin America.

In other words, the role of Chinese lending in Latin America seems to be quite dependent on circumstantial factors. Chinese loans do not constitute a geopolitical tool used to shape Latin American economic development. In fact, the empirical evidence presented above shows that Chinese lending flowing to Latin American is significantly motivated by simply commercial reasons rather than being part of an effort to project soft power or to exercise some extractive diplomacy by locking up natural resources in the region (Gallagher \& Irwin, 2015).

\section{New Dependency?: A preliminary conclusion}

The new relationship between Latin America and the global market is apparently defined by the regional capacity to take advantage of favourable business cycles and promote sustainable development. After the implementation of market-oriented reforms in the early 1990s, most of Latin American economies not only diversified their productive capacity but also change their role in the international markets. With only some few exceptions, trade links with North America and Europe are now more fluid and diverse. Intra-regional trade is also more dynamic, and governments in the region are actively seeking for stronger trade links with emerging economies in Asia and Africa. Even closed economies (e.g. Venezuela) are eager for new trade and investment partners. The abundant supply of natural resources and agricultural goods has made those goals more achievable and Latin American countries more attractive to developed and emerging economies. 
However, the structural weakness of the Latin American industrialization process and the volatility of international commodities prices have made the region quite susceptible to dramatic fluctuations in the global markets. Not surprisingly, a number of Latin American economies suffered the consequences of the 2008-09 financial crisis, the global commodity collapse, and the apparent slowing down of China's economic growth. Some scholars and pundits have argued that Latin America's reaction to global market fluctuations constitutes a symptom of a new pattern or model of development in the region. From their perspective, this pattern of economic insertion to the global market resembles old patterns of economic dependency. The reorganization of global capitalism (to use dependency theory terminology) added new pressures to Latin American economies and they responded by specializing their production, focusing on commodity exports, and slowing down domestic industrialization. Therefore, according to these views, Latin American economies have once again a secondary and peripheral role in the international markets.

The economic relationship between China and Latin America seems to illustrate this situation quite well. Unfavourable trade balance for Latin America, massive flows of FDI and development loans from China, and the increasing importance of the Chinese government for Latin American countries' foreign policy prove this new dependent relationships. The evidence seems irrefutable. However, a closer look at the facts on the Sino-Latin American economic relationship allows us to see that such claims are rather inconclusive.

This paper provides consistent empirical evidence to demonstrate that trade relationships between China and Latin America are effectively unbalanced and there is a pattern of specialization that is not favourable for Latin American industrial sectors. However, this unbalanced relationship is not predominant for all countries in the region, and most importantly, for some economies (e.g. Chile or Brazil), strong (and even relatively specialized) trade links with China have improved their strategic position in the global market.

This paper also shows that the so-called "dependent relationship" with China is limited to trade links. The penetration of Chinese capitals in the region is remarkable but still quite 
limited. Companies and governments in the region still rely heavily on Western creditors and development loans, and Chinese capitals have barely gone beyond oil, mining, and infrastructure sectors. Chinese investment in manufacturing or service sectors is only modest. Finally, state-to-state financing is rather limited and quite focused to a handful of countries, which makes Chinese diplomacy in the region less powerful. In fact, Chinese presence in the region seems to be market-oriented only; it seems to early to consider it a real geopolitical power in the region.

\section{References}

Amal, Mohamed, Tomio, Bruno Thiago, \& Raboch, Henrique. 2010. Determinants of Foreign Direct Investment in Latin America. Revista de Globalización, Competitividad y Gobernabilidad, 4(3), 116-133.

Avendano, Rolando, \& Dayton-Johnson, Jeff. 2015. Central America, China, and the US: What Prospects for Development? Pacific Affairs, 88(4), 813-847.

Bengoa, Marta, \& Sanchez-Robles, Blanca. 2003. Foreign direct investment, economic freedom and growth: new evidence from Latin America. European Journal of Political Economy, 19(3), 529-545.

Biglaiser, Glen, \& DeRouen, Karl R. 2006. Economic reforms and inflows of foreign direct investment in Latin America. Latin American Research Review, 41(1), 51-75.

Blonigen, Bruce A, \& Piger, Jeremy. 2014. Determinants of foreign direct investment. Canadian Journal of Economics/Revue canadienne d'économique, 47(3), 775-812.

Büthe, Tim, \& Milner, Helen V. 2008. The politics of foreign direct investment into developing countries: increasing FDI through international trade agreements? American Journal of Political Science, 52(4), 741-762. 
Cardoso, Fernando Henrique, \& Faletto, Enzo. 1979. Dependency and development in Latin America. Univ of California Press.

Cardoso, Henrique Fernando. 1972. Dependent capitalist development in Latin America. New Left Review, 83.

Carr, David L, Markusen, James R, \& Maskus, Keith E. 2001. Estimating the knowledgecapital model of the multinational enterprise. The American Economic Review, 91(3), 693-708.

Chen, Taotao, \& Perez, Miguel. 2014. Chinese foreign direct investment in Latin America and the Caribbean. ECLAC Production and Development Series Working Papers.

Corrales, Javier, \& Penfold-Becerra, Michael. 2011. Dragon in the tropics: Hugo Chávez and the political economy of revolution in Venezuela. Brookings Institution Press.

Di Giovanni, Julian. 2005. What drives capital flows? The case of cross-border M\&A activity and financial deepening. Journal of international Economics, 65(1), 127-149.

ECLAC. 2015. Latin America and the Caribbean and China: towards a new era in economic cooperation. UN-ECLAC.

Ellis, Robert Evan. 2009. China in Latin America: the whats and wherefores. Vol. 46. Lynne Rienner Publishers Boulder, Colo.

Furtado, Celso. 1976. Economic development of Latin America: historical background and contemporary problems. Vol. 8. Cambridge University Press.

Gachúz, Juan Carlos. 2012. Chiles economic and political relationship with China. Journal of Current Chinese Affairs, 41(1), 133-154.

Gallagher, Kevin, \& Myers, Margaret. 2015. China-Latin America Finance Database. Database available at ¡http://www.thedialogue.orgi. 
Gallagher, Kevin, \& Porzecanski, Roberto. 2010. The dragon in the room: China and the future of Latin American industrialization. Stanford University Press.

Gallagher, Kevin, Koleski, Katherine, \& Irwin, Amos. 2013. Chinese Finance in Latin America: Brown or Green?

Gallagher, Kevin P. 2016. The China triangle: Latin America's China boom and the fate of the Washington consensus. Oxford University Press.

Gallagher, Kevin P, \& Irwin, Amos. 2015. China's Economic Statecraft in Latin America: Evidence from China's Policy Banks. Pacific Affairs, 88(1), 99-121.

Gallagher, Kevin P, Irwin, Amos, \& Koleski, Katherine. 2012. The new banks in town: Chinese finance in Latin America. Inter-American Dialogue Report.

Garcia-Herrero, Alicia, Xia, Le, \& Casanova, Carlos. 2015. Chinese outbound foreign direct investment: How much goes where after round-tripping and offshoring? BBVA Research Working Papers.

Hausmann, Ricardo. 2011. Structural transformation and economic growth in Latin America. In: Ocampo, José Antonio, \& Ros, Jaime (eds), Oxford Handbook of Latin American Economics. Oxford University Press.

Jenkins, Rhys Owen, \& Peters, Enrique Dussel. 2009. China and Latin America: Economic relations in the twenty-first century. DIE.

Julio, Brandon, \& Yook, Youngsuk. 2016. Policy Uncertainty, Irreversibility, and CrossBorder Flows of Capital. Journal of International Economics, 103, 13-26.

Kaplan, Stephen. 2015. Banking Unconditionally: The Political Economy of Chinese Finance in Latin America. Unpublished manuscript.

Kaplan, Stephen B. 2013. Globalization and austerity politics in Latin America. Cambridge University Press. 
Lall, Sanjaya, \& Weiss, John. 2007. China and Latin America: Trade Competition, 19902002. Development Centre Studies, 85-107.

Ministry of Commerce, People's Republic of China. 2015. 2014 Statistical Bulletin of China's Outward Foreign Direct Investment. Ministry of Commerce, People's Republic of China.

Montero, Alfred P. 2008. Macroeconomic deeds, not reform words: The determinants of foreign direct investment in Latin America. Latin American Research Review, 43(1), 5583.

Myers, Margaret, \& Wise, Carol. 2016. The Political Economy of China-Latin America Relations in the New Millennium: Brave New World. Routledge.

Nolan, Peter. 2005. China at the Crossroads. Journal of Chinese Economic and Business Studies, 3(1), 1-22.

OECD/ECLAC/CAF. 2015. Latin American economic outlook 2016: towards a new partnership with China. OECD.

Oliveira, Gustavo, \& Schneider, Mindi. 2016. The politics of flexing soybeans: China, Brazil and global agroindustrial restructuring. Journal of Peasant Studies, 43(1), 167-194.

Ortiz, Jaime. 2012. Déjà VU: Latin America and Its New Trade Dependency... This Time with China. Latin American Research Review, 47(3), 175-190.

Palma, José Gabriel. 2011. Why has productivity growth stagnated in most Latin American countries since the neoliberal reforms? In: Ocampo, José Antonio, \& Ros, Jaime (eds), Oxford Handbook of Latin American Economics. Oxford University Press.

Palma, José Gabriel. 2016. The dependency school and its aftermath: why Latin Americas critical thinking switched from one type of absolute certainties to another. In: Reinert, Erik; Ghosh, Jayati, \& Kattel, Rainier (eds), Handbook of Alternative Theories of Economic Development. Edward Elgar Publishing. 
Perrotti, Daniel. 2015. The People's Republic of China and Latin America: the impact of Chinese economic growth on Latin American exports. CEPAL Review, 116, 47-59.

PRS. 2015. International Country Risk Guide Database.

Staats, Joseph L, \& Biglaiser, Glen. 2012. Foreign direct investment in Latin America: the importance of judicial strength and rule of law. International Studies Quarterly, 56(1), $193-202$.

Tuman, John P, \& Emmert, Craig F. 1999. Explaining Japanese foreign direct investment in Latin America, 1979-1992. Social science quarterly, 539-555.

Wei, Shang-Jin. 2000. How taxing is corruption on international investors? Review of Economics and Statistics, 82(1), 1-11.

Wise, Carol. 2016. China and Latin America's Emerging Economies: New Realities amid Old Challenges. Latin American Policy, 7(1), 26-51.

Wise, Carol, \& Quiliconi, Cintía. 2007. China's surge in Latin American markets: Policy challenges and responses. Politics \& Policy, 35(3), 410-438. 


\section{Appendices}

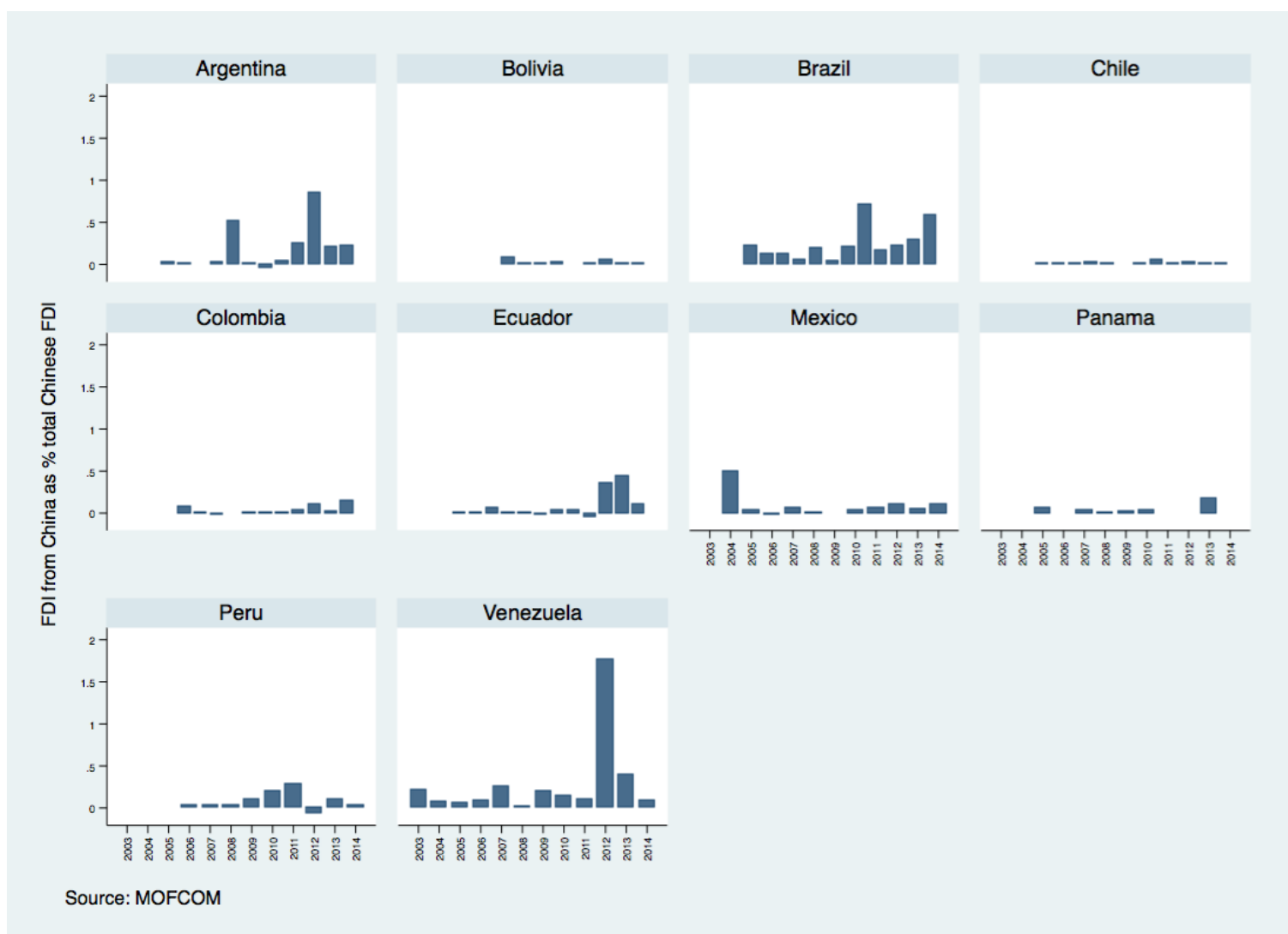

Figure A1: FDI flows from China to Latin America (as \% total outward Chinese FDI). Source: Chinese government, MOFCOM 


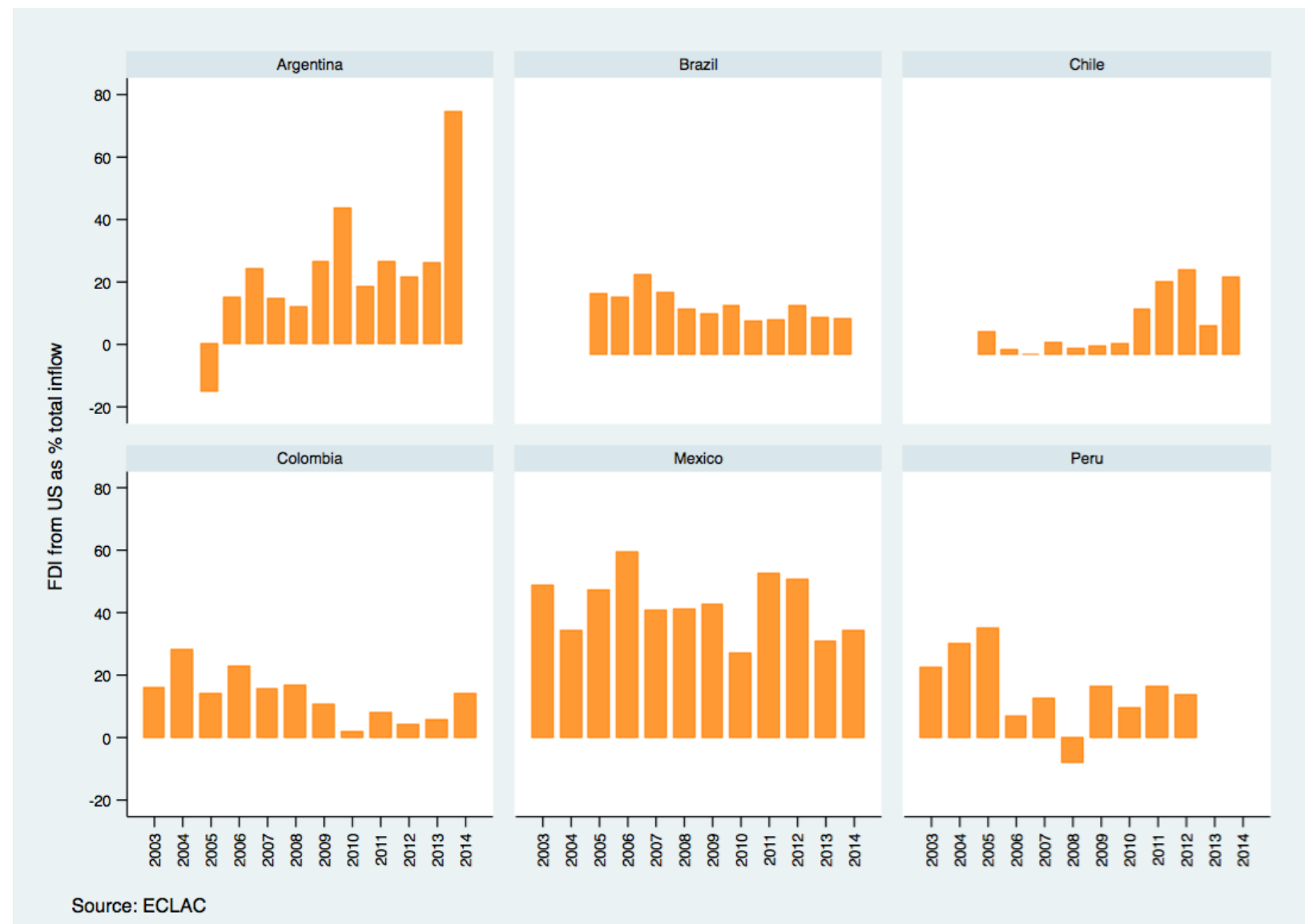

Figure A2: FDI flows from US to Latin America (as \% total inward FDI). Source: ECLAC 


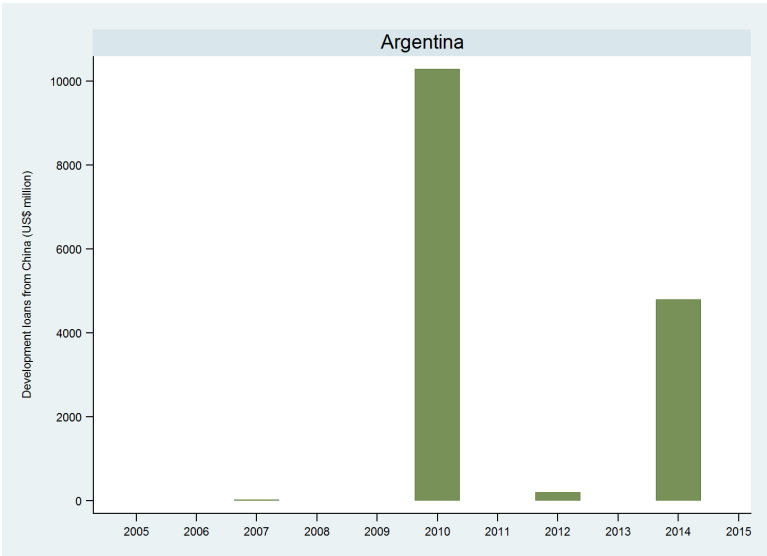

(a)

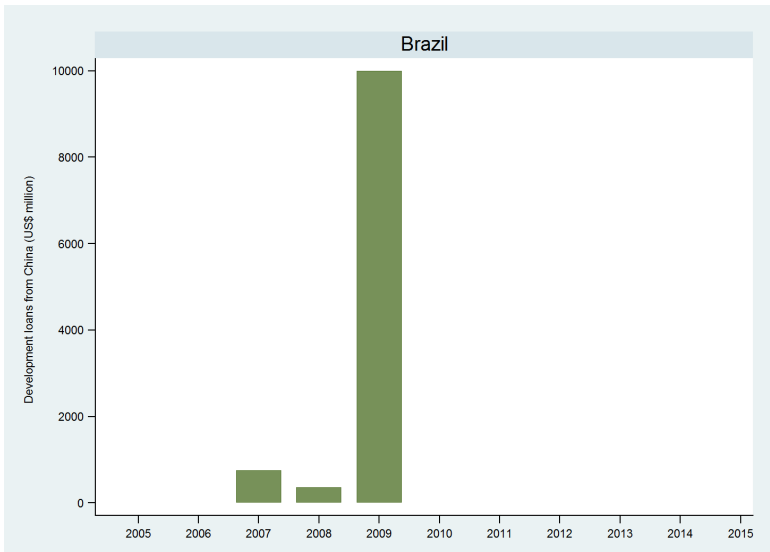

(c)

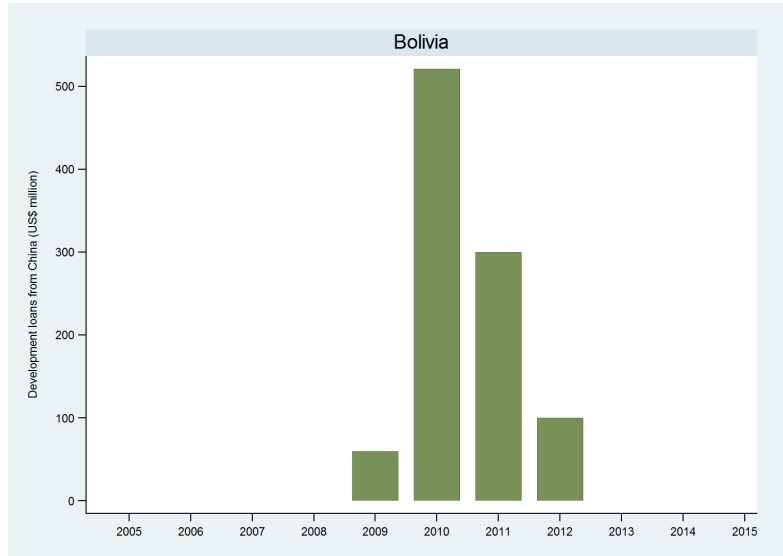

(b)

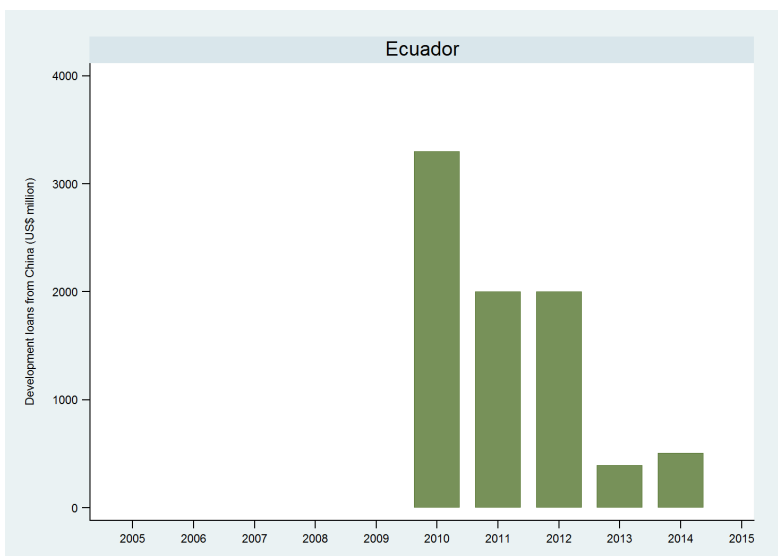

(d)

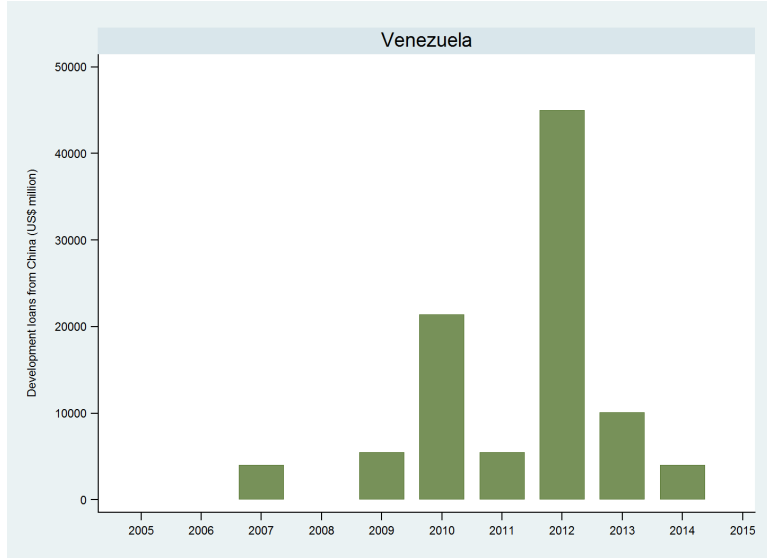

(e)

Figure A3: Chinese loans to Latin America (US\$ million). Source: Gallagher \& Myers (2015) 